\title{
Combining limnology and palaeolimnology to investigate recent regime shifts in a shallow, eutrophic lake
}

\author{
Linda Randsalu-Wendrup - Daniel J. Conley • Jacob Carstensen • \\ Lars-Anders Hansson • Christer Brönmark • Sherilyn C. Fritz • \\ Preetam Choudhary $\cdot$ Joyanto Routh $\cdot$ Dan Hammarlund
}

Received: 18 June 2013/ Accepted: 18 January 2014/Published online: 28 January 2014

(C) The Author(s) 2014. This article is published with open access at Springerlink.com

\begin{abstract}
In this study, we demonstrate that an integrated approach, combining palaeolimnological records and limnological monitoring data, can increase our understanding of changing ecological patterns and processes in shallow lakes. We focused on recent regime shifts in shallow Lake Krankesjön, southern Sweden, including the collapse of the clearwater state in 1975 and its subsequent recovery in the late 1980s. We used diatom, hydrocarbon and biogenic silica sediment records, in concert with limnological data sets on nutrient concentrations, water clarity, chlorophyll- $a$ and water depth, to investigate the shifts. The shift from clear to turbid conditions was
\end{abstract}

L. Randsalu-Wendrup ( $₫)$ · D. J. Conley ·

D. Hammarlund

Department of Geology, Quaternary Sciences, Lund

University, Sölvegatan 12, 22362 Lund, Sweden

e-mail: linda.randsalu_wendrup@geol.lu.se

D. J. Conley

e-mail: Daniel.conley@geol.lu.se

D. Hammarlund

e-mail: Dan.hammarlund@geol.lu.se

J. Carstensen

Department of Bioscience, Aarhus University,

P.O. Box 358, 4000 Roskilde, Denmark

e-mail: jac@dmu.dk

\section{L.-A. Hansson · C. Brönmark}

Department of Biology, Aquatic Ecology, Lund University, Sölvegatan 37, 22362 Lund, Sweden

e-mail: Lars-Anders.Hansson@biol.lu.se abrupt and occurred over 1 to 2 years, whereas recovery of the clear-water state was more gradual, taking 4-5 years. In 1978, shortly after the first regime shift in water clarity, the diatom community underwent a significant shift. It became less diverse, with decreased abundance of epiphytic and planktonic taxa. Despite rising phosphorus concentrations and lower abundance of submerged macrophytes, Lake Krankesjön has remained in the clear-water state over the past 20 years, although this state seems to be increasingly unstable and susceptible to collapse. The complex reactions of the entire lake ecosystem to major changes in lake-water clarity, as shown by the

\author{
C. Brönmark \\ e-mail: Christer.Bronmark@biol.lu.se \\ S. C. Fritz \\ Department of Earth and Atmospheric Sciences, \\ University of Nebraska, Lincoln, NE 68588, USA \\ e-mail: Sfritz2@unl.edu \\ P. Choudhary \\ Limnology Department, Evolutionary Biology Centre, \\ Uppsala University, Norbyvägen 18D, 75236 Uppsala, \\ Sweden \\ e-mail: preetam.choudhary@ebc.uu.se \\ J. Routh \\ Department of Water and Environmental Studies, \\ Linköping University, 58183 Linköping, Sweden \\ e-mail: joyanto.routh@liu.se
}


palaeolimnological variables investigated in this study, emphasize the importance of careful lake and catchment management if a stable, clear-water state is desired.

Keywords Regime shift · Monitoring ·

Ecosystem - Alternative stable state - Diatoms ·

Hydrocarbons

\section{Introduction}

Abrupt shifts in ecosystem structure and function are often described as "regime shifts," i.e. sudden and large events that lead to rapid ecosystem reconfiguration from one alternative state to another (Lees et al. 2006; Andersen et al. 2009). Regime shifts occur in multiple ecosystem types (Scheffer et al. 2001), including marine environments (Collie et al. 2004; Spencer et al. 2011), Arctic lakes (Smol et al. 2005), brackish lagoons (Jeppesen et al. 2007), terrestrial systems (Dearing 2008) and coastal areas (Conley et al. 2009; Duarte et al. 2009). These shifts are, however, especially well-documented in shallow lakes, and are often associated with anthropogenic eutrophication (McGowan et al. 2005; Hargeby et al. 2007; Scheffer and Jeppesen 2007; Scheffer and van Nes 2007; Zimmer et al. 2009; Hobbs et al. 2012). The transition of a shallow lake from a clear-water, macrophyte-dominated regime to a turbid, phytoplankton regime has been described theoretically by, for example, Scheffer et al. (1993) and Scheffer and Carpenter (2003). Theory predicts that increasing nutrient concentrations decrease the stability of the clear-water regime until a critical threshold is reached, at which time the lake shifts to the turbid regime. Reestablishment of the clear-water regime is not possible unless nutrient concentrations are reduced substantially and the system displays hysteresis (Scheffer et al. 2001; Andersen et al. 2009). An external perturbation can cause a regime shift in the lake at moderate nutrient levels, but at low and high nutrient concentrations, clear and turbid regimes are the only possible states (Scheffer et al. 1993; Scheffer and Carpenter 2003).

Lake Krankesjön, in southern Sweden (Fig. 1), is a shallow, eutrophic lake with a history of structural shifts between two alternative states, one clear and macrophyte-dominated and the other turbid and algal- dominated, in spite of supposedly very little change in external nutrient loading (Blindow et al. 2006). These shifts have been documented for almost a century, in reports on the abundance of herbivorous waterfowl and notes on water clarity (Swanberg 1931; Almestrand and Lundh 1951; Thomasson 1956; Forsberg 1964; Hansson et al. 2010), which are summarized in Fig. 2b. During the 1920s, there were dense beds of charophytes in the shallow lake, which continued to be dominated by charophyte vegetation until the mid1940s, after which there was a short period when submerged plants were absent (Almestrand and Lundh 1951; Blindow 1992b). By 1948, the submerged vegetation had recovered in Lake Krankesjön, and in the 1950s and 1960s submerged vegetation was well developed (Karlsson et al. 1976). A shift to the turbid state occurred in the mid-1970s, and the lake had sparse submerged vegetation for almost a decade (Blindow et al. 2006). In the mid-1980s, submerged vegetation rapidly started to recolonize the lake, and since the late 1980s, the lake has been in a clear-water state, with abundant macrophyte beds. Periods of temporary instability of the clear-water state, however, occurred in 1997 and 1999 (Blindow et al. 2002), and most recently, during 2011-2012 (Brönmark, C. and Hansson L-A., unpublished data).

Lake Krankesjön is considered a waterfowl habitat of international importance and is included in both the international Ramsar Convention of Wetlands and the EU network Natura 2000. The clear-water state of the lake is generally preferred from a human perspective, because greater water transparency, higher biodiversity and fewer problems with toxin-producing phytoplankton produce higher recreational value. The clear-water state is also favored from a conservation standpoint for managing waterfowl in Lake Krankesjön.

Sayer et al. (2010) suggest that the combination of contemporary ecology and palaeolimnology can be a powerful means to assess the dynamics of shallowlake ecosystems on multiple timescales. Records of multiple variables obtained from sediment successions can be used to pose and test ecological theories across time scales beyond the reach of monitoring data, whereas studies of contemporary aquatic ecology provide insights into habitat preferences, seasonality and interactions of organisms. The combination of long-term observational data sets and recent sediment records can yield long-term records of lake histories (Battarbee et al. 2005). In this study we combined 
A

B

C

D

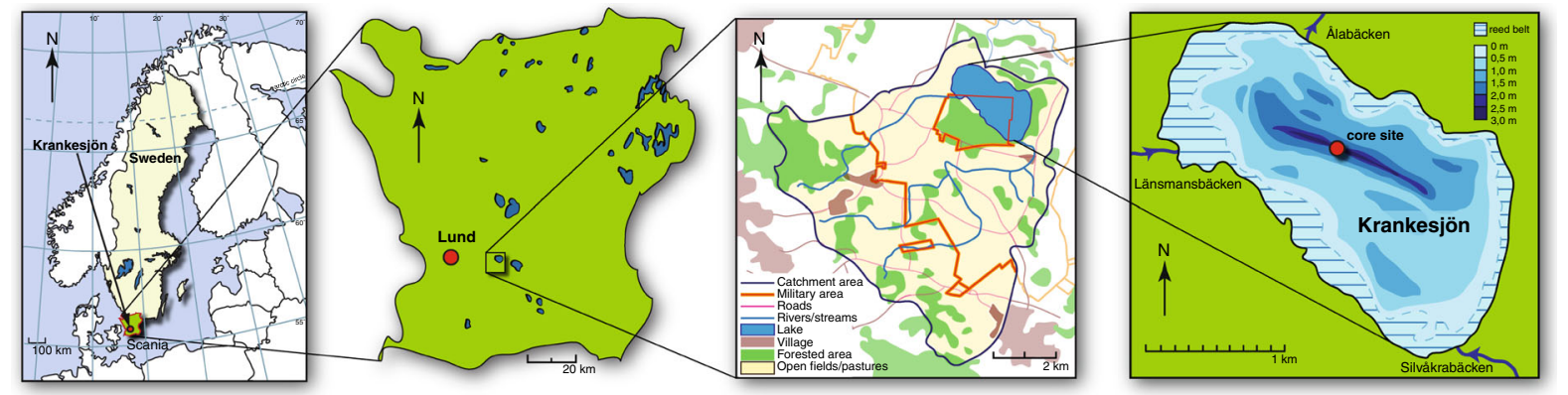

Fig. 1 a Map of Scandinavia showing the location of Lake Krankesjön in southern Sweden. b Map of the province of Scania. c Map of the catchment area surrounding Lake
Krankesjön. d Close-up map of the lake showing inlets, outlet, bathymetry and sediment sampling site
Fig. 2 a Age-depth model for the Krankesjön sediment sequence based on ${ }^{210} \mathrm{~Pb}$ dating. The blue shading indicates dating uncertainty envelopes, with $2 \sigma$ error. The grey shading indicates a period with turbid conditions, with the dashed shading indicating the dating uncertainty. b Overview of the development of Krankesjön during the studied time period. Data from Blindow (1992a), Hargeby et al. (2007), The Swedish Fortification Agency (Fortifikationsverket) and recent monitoring
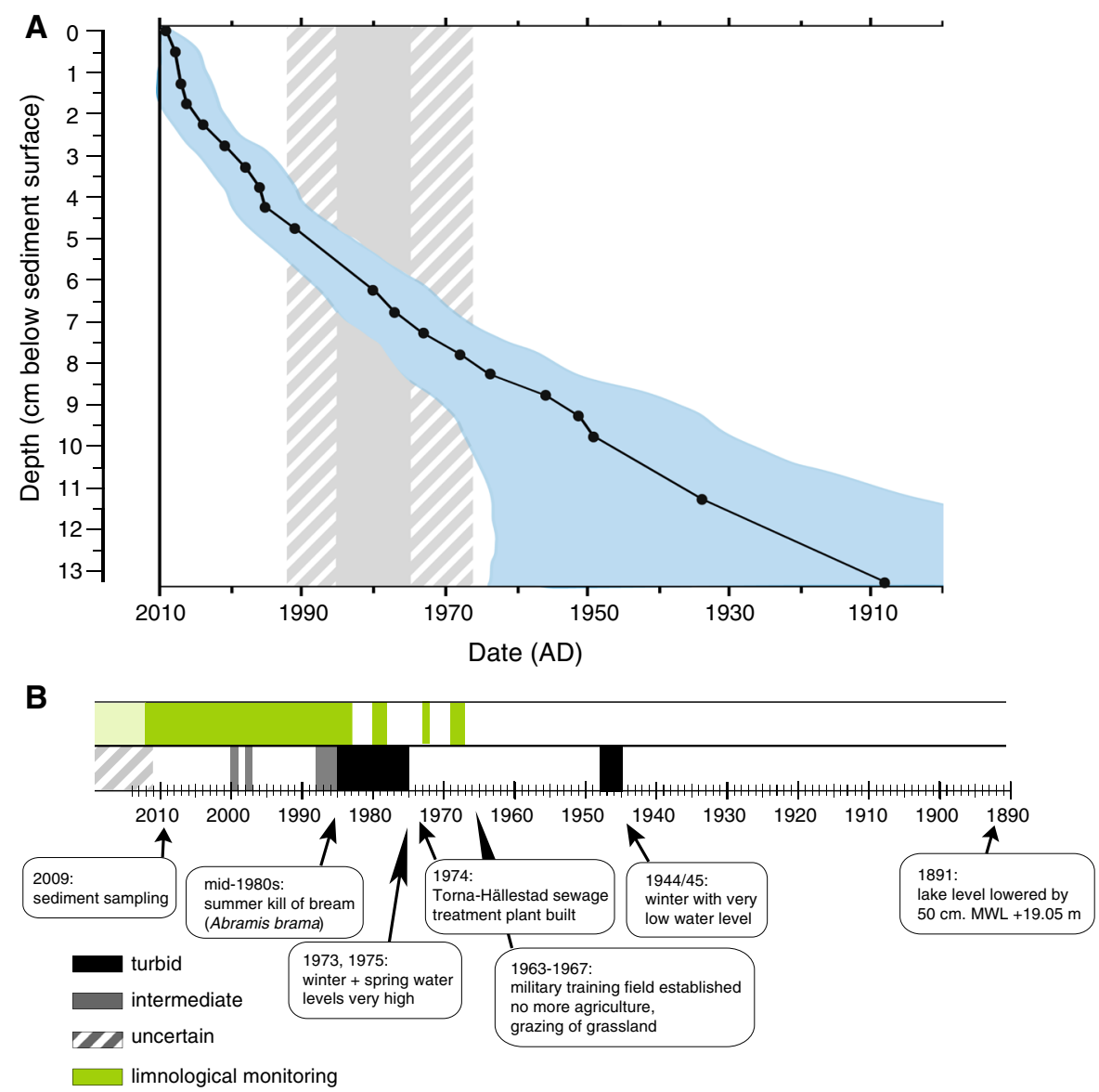

limnological monitoring data with palaeolimnological diatom, hydrocarbon and biogenic silica records, to make an integrated assessment of the shifts between turbid- and clear-water states in Lake Krankesjön. We focused on the regime shifts during the mid-1970s and mid-1980s, and examined how they were recorded by the monitoring data and whether they were recorded in the sediment. Considering that regime shifts have been documented since the 1920s in Lake Krankesjön, we focused on the recent lake sediments, covering the 
period from ca. 1900-2009, which enabled us to compare the sediment record to the limnologically documented changes.

\section{Materials and methods}

Site description, core collection and chronology

Lake Krankesjön is situated in the southernmost part of Sweden $\left(55^{\circ} 42^{\prime} \mathrm{N}, 13^{\circ} 28^{\prime} \mathrm{E}\right)$, approximately $20 \mathrm{~km}$ east of the city of Lund (Fig. 1). The lake is shallow (maximum depth $3.2 \mathrm{~m}$, median depth $1.5 \mathrm{~m}$ ), with a water retention time of 2.3 months, and it is moderately eutrophic and calcium-rich. It has a surface area of 3.4 and a $53-\mathrm{km}^{2}$ catchment that is dominated by arable land $(59 \%)$, pastures and open fields (17\%) and forest (16\%). Much of the land in forest and open fields is part of a military training area that surrounds the lake. The lake has two inflows, the River Länsmansbäcken, which enters from the west, and the River Silvåkrabäcken, which enters from the southeast. The River Alabäcken is the outlet, in the northern part of the lake.

A 76-cm sediment sequence was collected from the ice in February 2009, using a crust-freeze sampler (Renberg 1981). The frozen sediment sequence was subsampled at the Department of Ecology and Environmental Science at Umeå University into 151 contiguous samples, each $0.5 \mathrm{~cm}$ thick, except the uppermost 1-cm-thick sample, using methods described by Renberg (1981).

The uppermost $14 \mathrm{~cm}$ of the sediment sequence was analyzed, providing 27 samples that were freezedried and homogenized prior to other analyses. The sequence was dated by measurement of ${ }^{210} \mathrm{~Pb},{ }^{226} \mathrm{Ra}$ and ${ }^{137} \mathrm{Cs}$, using gamma spectrometry, at the Gamma Dating Centre, Institute of Geography, University of Copenhagen. ${ }^{210} \mathrm{~Pb}$ ages were calculated using the constant rate of supply (CRS) model (Appleby 2001).

\section{Diatom analysis}

Approximately $0.01 \mathrm{~g}$ of freeze-dried sediment was digested using the water-bath technique with $30 \%$ $\mathrm{H}_{2} \mathrm{O}_{2}$ (Battarbee et al. 2001). Diatom concentrations (valves $\mathrm{mg}^{-1}$ ) were determined by adding DVB (divinylbenzene) spheres to the cleaned samples (Battarbee and Kneen 1982). Cleaned subsamples were dried onto cover slips and mounted onto microscope slides using Zrax (R.I 1.7+). At least 600 diatom valves (minimum 200 non-Fragilariaceae) were counted in each subsample under a light microscope at $\times 1,000$ using phase-contrast optics. Diatom taxonomy followed Krammer and Lange-Bertalot (1986, 1988, 1991a, b), Williams and Round (1987), Lange-Bertalot and Metzeltin (1996), Round and Bukhtiyarova (1996), LangeBertalot (1999) and Håkansson (2002). In total, 72 taxa were identified. All diatom data are expressed as relative percent abundances and were reduced to 13 taxa. Only taxa with abundances exceeding $3 \%$ of the total were included in the statistical analyses. Fragilarioid taxa comprised up to $89 \%$ of the valves counted in each sample, and therefore the non-fragilarioid taxa were also examined separately, using the 24 taxa with abundances exceeding $3 \%$ of total non-fragilarioid taxa. The diatom accumulation rate (DAR) and Hill's N2 diversity index (Hill 1973) were calculated using all identified taxa.

\section{Geochemical analyses}

Hydrocarbons were extracted from approximately 1-2 $\mathrm{g}$ of freeze-dried sediment with a mixture of dichloromethane and methanol $(9: 1 \mathrm{v} / \mathrm{v})$. A Dionex Accelerated Solvent Extractor 300 was used (programmed for three extraction cycles at 1,000 psi and $100{ }^{\circ} \mathrm{C}$ ). The lipid extracts were reduced in volume by using a Büchi Rotovapor and injected in pulsed splitless mode into an Agilent 6890 gas chromatograph equipped with a CIS-4 Gerstel inlet and a DB5MS column $(30 \mathrm{~m} \times 0.25 \mathrm{~mm}$ i.d. $\times 0.25 \mu \mathrm{m}$ film $)$. Oven temperature was held at $35^{\circ} \mathrm{C}$ for $6 \mathrm{~min}$, increased to $300{ }^{\circ} \mathrm{C}$ at $5{ }^{\circ} \mathrm{C} \mathrm{min}{ }^{-1}$ and held there for 20 min. The chromatograph was interfaced with an Agilent 5973 mass spectrometer operated at $70 \mathrm{eV}$ in full-scan mode $(\mathrm{m} / \mathrm{z}$ 50-500 amu). External and internal standards (S-4066 from CHIRON, Norway and deuterated perylene from Cambridge Laboratory, USA) were used for quantification.

Biogenic silica was analyzed following the wet chemical digestion technique described by Conley and Schelske (2001). Results are presented as wt $\% \mathrm{SiO}_{2}$ of total dry weight.

Monitoring data

Lake Krankesjön has been the focus of numerous research projects, as well as national and regional 
monitoring, since the late 1960s (Fig. 2b). We obtained and merged data sets from the Swedish University of Agricultural Sciences and the Aquatic Ecology Unit of the Department of Biology, Lund University, and selected variables that aid in describing and understanding the shifts between clear and turbid states (Fig. 3). Sampling was less consistent at times, and the variables analyzed have differed, but since the mid-1980s, the sampling protocol has been fairly stable. Before 1983 there was only one waterquality sample collected per year, in July-August. Water-level data (year-round monthly measurements) from 1946 to present (excluding 1990-1994) were obtained from the County Administrative Board of Skåne (Länsstyrelsen) and the Swedish Fortification Agency (Fortifikationsverket).

Statistical analyses

Yearly means (March-September) of nutrients, chlorophyll- $a$, turbidity, $\mathrm{pH}$ and Secchi depth were calculated from the monitoring data (all log-transformed except $\mathrm{pH}$ and Secchi depth) as marginal means from a General Linear Model that accounted for differences in months of sampling across years (Carstensen et al. 2006). Means of log-transformed variables were backtransformed using the exponential function to represent geometric means.
Stratigraphic diatom assemblage zones (DAZ) were determined through regression tree analysis (De'ath and Fabricius 2000), using the mvpart package (De'ath 2012) for the R statistical software. The smallest tree within one standard error of the tree with the lowest cross-validation relative error was chosen, producing two zones. A detrended correspondence analysis (DCA), performed using the vegan package (Oksanen et al. 2012) in R, revealed that the gradient length in the diatom data was short ( -2 SD units), and therefore principal component analysis (PCA) was performed on Hellinger-transformed diatom data using the same package. One PCA axis was identified as explaining significant proportions of the variance in the stratigraphic data when compared to the broken stick (null) distribution. This axis explained $46 \%$ of the variance.

\section{Results}

\section{Chronology}

Unsupported ${ }^{210} \mathrm{~Pb}$ activity in the sediment sequence is generally low, with activities consistently $<0.19 \mathrm{~Bq} \mathrm{~g}^{-1}$ dry material, which could indicate temporary erosion at the core site. Low activities, in combination with small sample sizes, led to rather

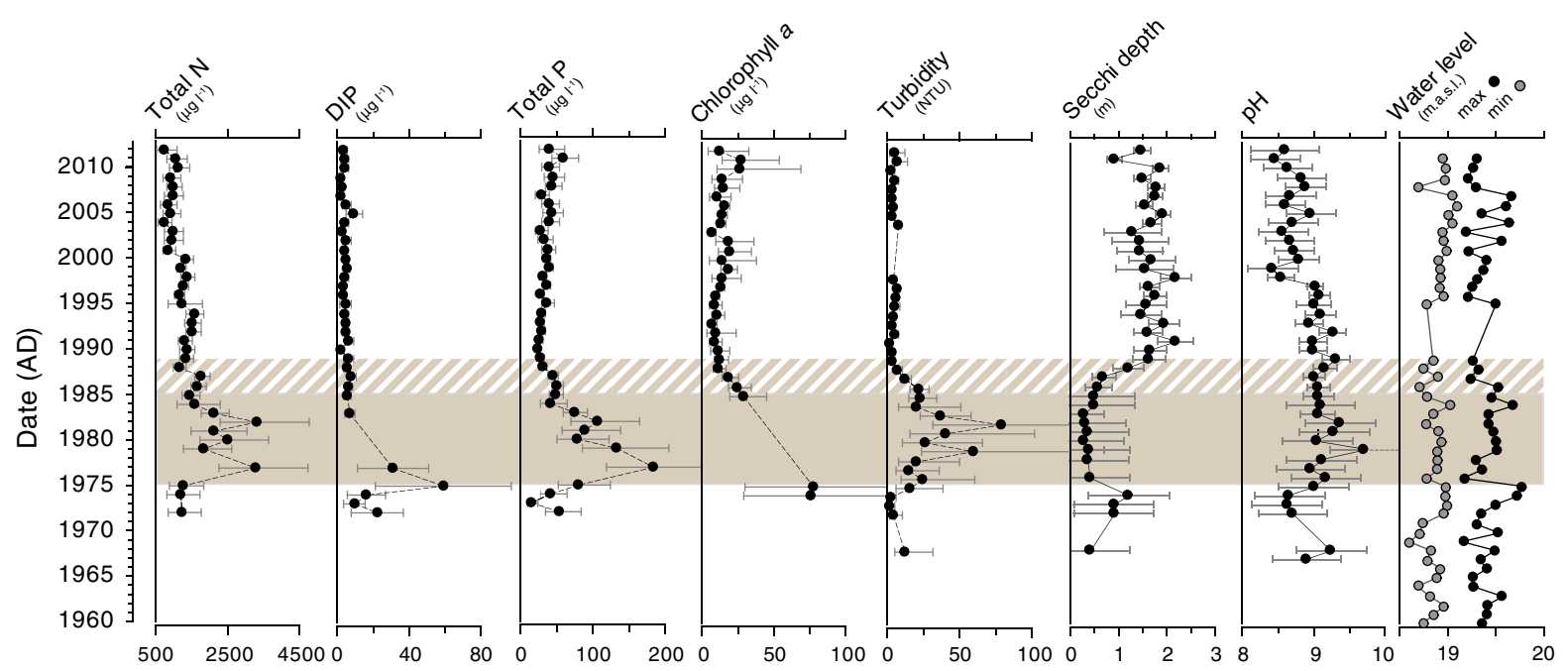

Fig. 3 Yearly means (Mar-Sep) of monitoring data from Lake Krankesjön, and water level range ( $\min$ and $\max$ ) from The County Administrative Board of Skåne (Länsstyrelsen) and the Swedish Fortification Agency (Fortifikationsverket). The brown shading indicates turbid conditions with the dashed shading indicating intermediate conditions. Error bars mark the $95 \%$ confidence interval of the means 
large error bars on the radiometric data (Fig. 2a). Application of the CRS dating model (Appleby 2001) to the unsupported ${ }^{210} \mathrm{~Pb}$ data, constrained by ${ }^{137} \mathrm{Cs}$, suggests a mean sedimentation rate of $0.15 \mathrm{~cm}_{\text {year }}{ }^{-1}$ over the last $\sim 100$ years, with increasing rates, ranging from 0.4 to $0.7 \mathrm{~cm} \mathrm{year}^{-1}$, in the surface sediments ( $0-2 \mathrm{~cm}$ depth). Sampling resolution in the core is, on average, $\sim 3$ years sample ${ }^{-1}$.

\section{Monitoring data}

During the 1960s and early 1970s, Lake Krankesjön was in a clear-water state (Fig. 2b), but by 1975 submerged vegetation was completely absent (Karlsson et al. 1976). This was accompanied by a shift to turbid conditions. Secchi depth decreased from $0.9-1.2$ to $0.3-0.5 \mathrm{~m}$ and turbidity increased (Fig. 3). All nutrient concentrations increased along with the shift to the turbid state, in particular dissolved inorganic phosphorus (DIP), which reached $61 \mu \mathrm{g} \mathrm{L}^{-1}$ in August 1975 and total phosphorus (TP), which peaked at $186 \mu \mathrm{g} \mathrm{L}^{-1}$ in August 1977. These increases in lake-water phosphorus content suggest large releases of iron-bound phosphorus from sediments, as well as release associated with decomposition of organic matter following the decline of submerged macrophytes. DIP concentrations had returned to low levels at the end of the turbid phase (although there are no monitoring data for the period 1977-1983) and total phosphorus and total nitrogen concentrations remained high until the early 1980s. Around 1984, Potamogeton pectinatus and characeans started to recolonize the lake, and from 1985 recolonization was rapid and the lake shifted to a clear-water state (Blindow 1992b). This is evident from turbidity values, which were high during the turbid state and decreased over 3-4 years following macrophyte recolonization. Secchi depth similarly increased to $\sim 1.5 \mathrm{~m}$ during those years and has remained between 1.5 and $2.0 \mathrm{~m}$ to the present (Fig. 3). TP concentrations increased around 1975 and then decreased during the remainder of the turbid state. After that, total phosphorus remained low, but displayed an increasing tendency since 1990. On the other hand, total nitrogen concentrations decreased steadily since the turbid state. Chlorophyll- $a$ levels were not measured during the turbid period, but declined significantly during 1985-1990 relative to measurements taken in 1974 and 1975. After 1990, chlorophyll- $a$ increased, similar to total phosphorus. Water level was unusually high prior to the shift
Fig. 4 a Diatom stratigraphy of the Lake Krankesjön sediment sequence, showing the major ( $>3 \%$ ) taxa as relative abundance (\%), diatom assemblage zones (DAZ), and proportion of Fragilariaceae and non-Fragilariaceae taxa (\%). b Major (>3\%) non-Fragilariaceae taxa as relative abundance (\%) within the non-Fragilariaceae community. Grey area turbid conditions, hatched dating uncertainty, as in Fig. 2

from clear-water to turbid conditions in 1975 (Fig. 3), especially during spring and summer (not shown).

\section{Palaeo-data}

The diatom community of Lake Krankesjön was completely dominated by benthic species (93-99\% relative abundance) throughout the investigated period. Thus, benthic primary production seems to have been an important contribution to whole-lake primary production, in both the turbid and the clear-water states. The studied sediment section was divided into two zones at ca. 1978 (Fig. 4), with different diatom community structures (Diatom Assemblage Zones; DAZ). The earlier zone (DAZ1) shows a lower abundance of diatoms, but a more diverse flora, whereas the later zone (DAZ2) shows slightly increasing diatom abundance, but lower diversity.

\section{Dazl (1900-1978)}

Fragilariaceae make up most of the diatom assemblage $(65-76 \%)$ in this zone, with Staurosira construens (Ehr.) Williams \& Round 1987, Staurosirella pinnata (Ehr.) Williams \& Round 1988, Pseudostaurosira brevistriata (Grunow in Van Heurk) Williams \& Round 1987 and Staurosirella leptostauron (Ehr.) Williams \& Round 1987 the most abundant fragilarioid species (Fig. 4a). The non-fragilarioid community is dominated by Geissleria schoenfeldii (Hustedt) Lange-Bertalot \& Metzeltin 1996, Achnanthidium minutissimum (Kützing) Czarnecki 1994, Amphora pediculus (Kützing) Grunow in Schmidt 1875, Achnanthidium exiguum (Grunow) Czarnecki 1994, Mastogloia smithii Thwaites 1856, and planktonic Aulacoseira ambigua (Grunow) Simonsen 1979 and Puncticulata radiosa (Lemmerman) Håkansson 2002 (Fig. 4b). Diatom productivity and abundance are often estimated from biogenic silica (BSi; Conley and Schelske 2001; Struyf and Conley 2009), and these concentrations are low throughout the zone (1.8-2.9 wt\%; Fig. 5). Similarly, diatom accumulation rates (DAR), another estimation of productivity 
A
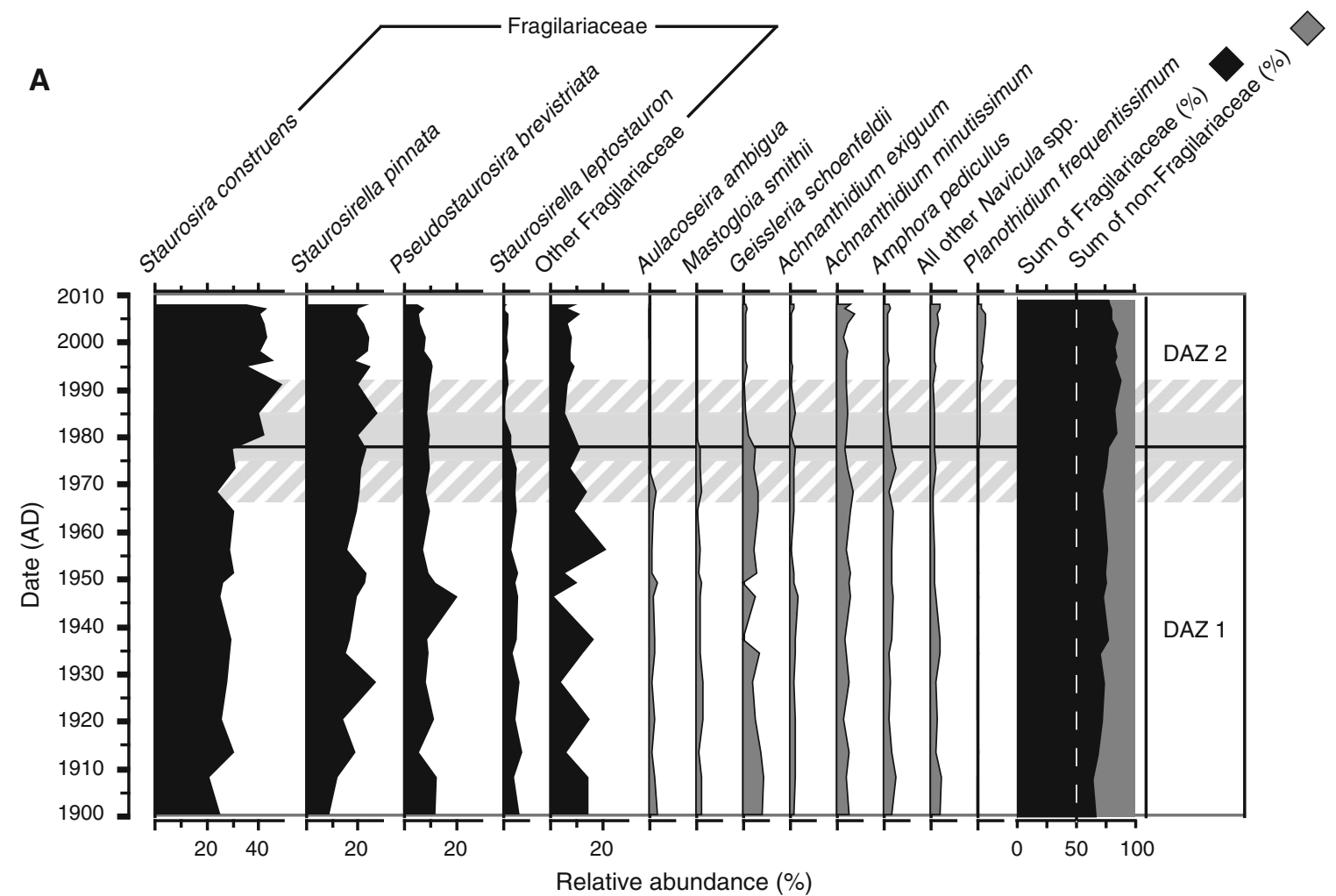

B

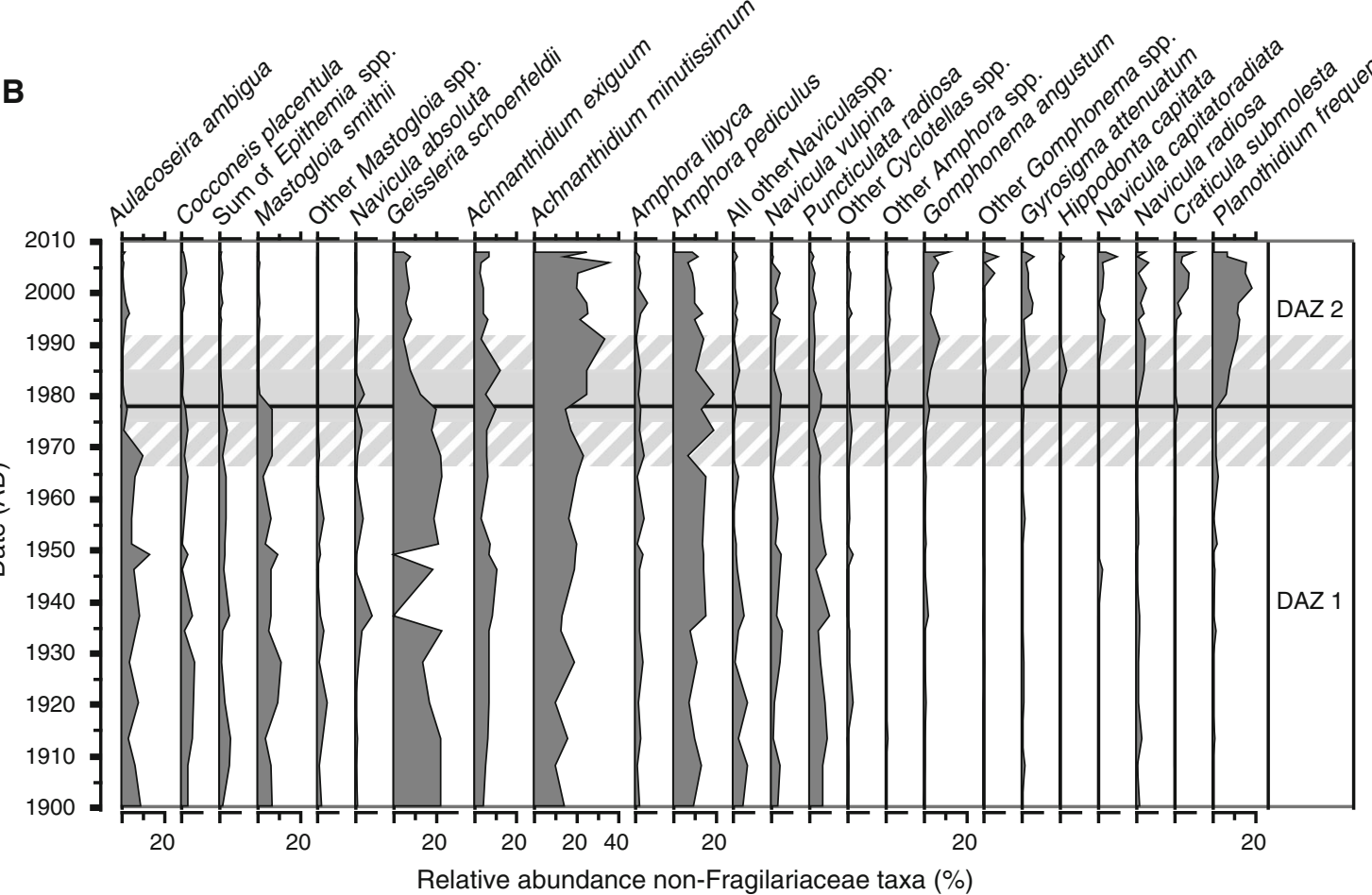


and/or preservation of diatoms, are relatively low throughout the zone, with a $\mathrm{DAR}_{\text {total }}$ of $40-320 \times 10^{4}$ valves $\mathrm{cm}^{-2}$ year $^{-1}$ (Fig. 5).

The hydrocarbon compositions of many algae and cyanobacteria are dominated by low molecular weight $n$ alkanes $\left(n-\mathrm{C}_{15,17,19}\right)$. In contrast, submerged and floatingleaved macrophytes have $n$-alkane distribution maxima at $\mathrm{C}_{21}, \mathrm{C}_{23}$ or $\mathrm{C}_{25}$ (Ficken et al. 2000; Meyers 2003). $\Sigma n$ $\mathrm{C}_{15,17,19}$ values are around $0.4-0.5 \mathrm{ng} \mathrm{gdw}^{-1}$ (gram dry weight) during the 1910s-1920s (Fig. 5), decline in the late $1920 \mathrm{~s}$ and remain low $\left(0.04-0.16 \mathrm{ng} \mathrm{gdw}^{-1}\right)$ throughout the zone, with the exception of a rise in the mid-1940s, a peak at $0.57 \mathrm{ng} \mathrm{gdw}^{-1}$ around 1950, and a rapid decline thereafter. The concentration of $\Sigma n$ $\mathrm{C}_{21,23,25}$ follows largely total hydrocarbon (HC) concentration variations, with fairly stable values between 7 and $18 \mathrm{ng} \mathrm{gdw}^{-1}$ throughout the zone, except for a minor peak of $25 \mathrm{ng} \mathrm{gdw}^{-1}$ around 1908 and a more prominent peak of $33 \mathrm{ng} \mathrm{gdw}^{-1}$ in the mid-1960s (Fig. 5).

\section{Daz2 (1978-2009)}

The proportion of fragilarioid taxa increases slightly after $c a$. 1978 , to between 78 and $89 \%$, but the dominant species remain the same. In the non-fragilarioid community, Achnanthidium minutissimum, A. exiguum and Amphora pediculus remain dominant, whereas $G$. schoenfeldii, M. smithii and the two dominant planktonic species, A. ambigua and $P$. radiosa, decrease markedly and are replaced by, above all, Planothidium frequentissimum (Lange-Bertalot) Round \& Bukhtiyarova 1996, Gomphonema angustum Agardh 1831, Navicula radiosa Kützing 1844 and Craticula submolesta (Hustedt) Lange-Bertalot 1996 (Fig. 4). The BSi content increases throughout the zone (from $2.4 \mathrm{wt} \%$ to a maximum of $7.7 \mathrm{wt} \%$ in 2006), indicating increased diatom productivity/abundance (Fig. 5). Diversity, as measured by Hill's N2 index, declines at the transition from DAZ1 to DAZ2 and remains low throughout this zone, with a slight peak ca. 1995 (Fig. 5). The change in sediment diatom composition is also visible on PCA axis 1 , where a shift from positive to negative values occurs at the beginning of DAZ2 (Fig. 5).

The $\Sigma n-C_{15,17,19}$ alkane concentrations show a second rapid increase starting at the beginning of DAZ2, with a peak value of about $0.94 \mathrm{ng} \mathrm{gdw}^{-1}$ in 1985. The values remain high for nearly 10 years before declining around 1998 to values around $0.40 \mathrm{ng} \mathrm{gdw}^{-1}$ (Fig. 5). $\Sigma n-\mathrm{C}_{21,23,25}$ values are low (2-10 $\left.\mathrm{ng} \mathrm{gdw}^{-1}\right)$, with the exception of one extreme value of $40 \mathrm{ng} \mathrm{gdw}^{-1}$ around 1985.

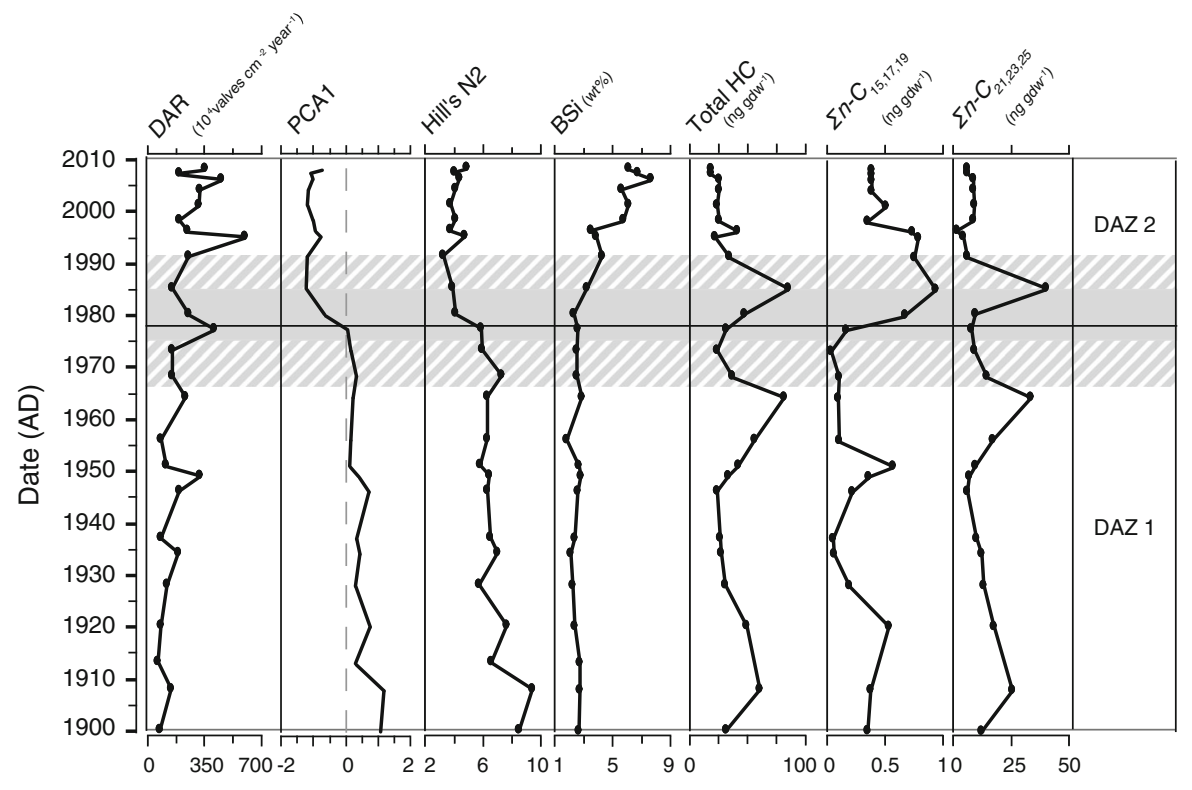

Fig. 5 Diatom accumulation rates (DAR), diatom PCA axis 1 scores, Hill's diversity index N2, wt $\%$ biogenic silica, total hydrocarbon concentration (ng per g dry weight), concentration of low and medium odd numbered $n$-alkanes $\left(\mathrm{C}_{15,17,19}\right.$ and $\mathrm{C}_{21,23,25}$ ). Diatom assemblage zones (DAZ) and grey shading follow Fig. 4 


\section{Discussion}

The historically described and previously investigated regime shifts in Lake Krankesjön from clear to turbid conditions in 1975, and turbid to clear conditions in the mid-1980s, are apparent in the monitoring data (Fig. 3), but rather unclear in the palaeolimnological data (Figs. 4, 5). The shift to turbid conditions in 1975 was registered as a rapid decrease in Secchi depth, an increase in turbidity and increases in total nutrient concentrations (Fig. 3). At roughly the same time, $\Sigma n$ $\mathrm{C}_{15,17,19}$ values increased. Because low molecular weight $n$-alkanes dominate the hydrocarbon composition of most aquatic algae (i.e. both diatoms and green algae) and photosynthetic bacteria (Choudhary et al. 2010), the increase in these compounds, combined with low diatom productivity, as indicated by low BSi values, could reflect dominance of cyanobacteria and green algae during most of the turbid state. The temporary increase in DAR, suggesting increased dominance of diatoms around 1977 (Fig. 5), may be connected to the high levels of dissolved inorganic phosphorus (DIP), which occurred at the beginning of, or possibly just before, the turbid period (Fig. 3). DIP concentrations are usually near detection limits in Lake Krankesjön, but in 1975 a considerable phosphate release occurred, which could be linked to the massive loss of submerged macrophytes and their subsequent decomposition. In addition, the enhanced accumulation of organic matter may have reduced redox conditions in the sediments, thereby enhancing releases of iron-bound phosphate. As indicated by the $\mathrm{HC}$, DAR and BSi data, cyanobacteria and green algae, which can maintain relatively high growth rates at low light intensities (Mur et al. 1999), seem to have outcompeted the diatoms and remained dominant throughout the turbid period, a pattern commonly seen under such conditions (Brönmark and Hansson 2005).

Within the diatom community, a significant shift occurred $c a$. 1978. Both PCA and regression tree analysis data show that the diatom assemblage of DAZ2 differs significantly from the previous assemblage (Fig. 4). At that point, periphytic G. shoenfeldii, M. smithii and Cocconeis placentula decreased in abundance along with planktonic species A. ambigua and $P$. radiosa. The periphytic forms $P$. frequentissimum, G. angustum, C. submolesta and S. construens increased at the same time. Whereas the decline in plant-attached species such as $C$. placentula can be interpreted as a direct response to the loss of submerged macrophytes, and thus the loss of habitats for epiphytic taxa (Sayer et al. 2006), increased turbidity and hence reduced light conditions may have been important in inhibiting planktonic production. The decline of $P$. radiosa and A. ambigua, species associated with mesotrophic rather than strongly eutrophic waters (Bennion and Appleby 2001), may also suggest eutrophication, and the diatom assemblage changes may in fact suggest slow eutrophication, with the macrophyte loss in the mid-1970s acting as a perturbation, which caused the apparent regime shift detected in the sediment data. As the diatom community changed, diversity, recorded by Hill's N2 diversity index, declined, indicating a less diverse diatom community post-1978. This, too, could be an indication of the slow eutrophication of the lake (Bennion et al. 1996, 2000).

The shift back to a clear-water state in the late 1980s was more gradual, with Secchi depth increasing and turbidity decreasing over a period of $c a$. 4-5 years, from 1985, when macrophytes were reestablished in the lake (Fig. 3). The shift to the clearwater state is, however, not easily identified stratigraphically, and it appears that the lake did not revert to the same clear-water conditions that prevailed prior to the turbid period. Increasing values of BSi and decreasing concentrations of low molecular weight $n$ alkanes imply lower influence of cyanobacteria and green algae and greater influence of diatoms in the basic food web during the past 20 years. The diatom record shows that as water clarity improved and diatom production increased, the community that was established around 1978 persisted into the clear-water state. Within the cyanobacterial community, however, large changes occurred in 1988, when small, noncolonial cyanobacteria were replaced by colonial, toxic Microcystis botrys and M. aeruginosa, as well as by the golden alga Dinobryon sociale (Blindow et al. 2006).

By combining monitoring and sediment data across the shifts from clear-water to turbid conditions, and back again from the mid 1970s to the mid 1980s, we found that regime shifts that were very apparent in the monitoring data were not clearly reflected in the palaeolimnological record. It appears that these regime shifts between clear and turbid states, which in some sense have become the model of regime shifts in shallow lakes (Scheffer et al. 1993, 2001), mainly 
affected the macrophyte community and higher food web of Lake Krankesjön, but not the entire, complex lake ecosystem. The diatom community was not clearly affected by the changes in water clarity and the record instead shows an underlying, slower change towards more eutrophic conditions, possibly amplified by the die-off of macrophytes in the mid-1970s. This eutrophication could have acted as an underlying mechanism behind the major regime shift, reducing the resilience of the system and making the clear-water state more vulnerable, hence matching the "classical" pattern of regime shift in shallow lakes (Scheffer et al. 1993, 2001; Scheffer and van Nes 2007). There are, however, suggestions that shifts between turbid- and clear-water states in shallow lakes in general are gradual, and not necessarily sudden processes (Scheffer and van Nes 2007; Sayer et al. 2010). van Nes et al. (2007) proposed a theory for cyclic shifts between alternative states in some shallow lakes, whereby submerged plants create a positive feedback for their own growth conditions by clearing the water, but in the long run undermine their position as the dominant primary producers by increasing nutrient retention and creating slow "internal eutrophication." This results in periods of low resilience, when a weak disturbance can trigger a shift to the turbid state. Hargeby et al. (2007) argued that this behaviour may be a factor behind the shifts in Lake Krankesjön and could explain the difficulties in identifying the specific causes behind the shifts in the lake.

Using additional sediment proxies for past limnological conditions, such as plant macrofossils and zooplankton remains, the natural lake state and variability, as reflected in the sediment record, might be better understood. It might make it possible to determine if and why the entire lake ecosystem did not respond to the major changes in water clarity. Extension of well-dated records beyond the last century could also shed light on whether the recent shifts between clear-water and turbid conditions are anomalies or part of a natural, cyclic lake behaviour. This, however, might prove challenging because the lake is calcareous and terrestrial macrofossils in the sediment are scarce.

In recent years, Lake Krankesjön seems to be changing, with increasing TP levels and lower abundance of characeans (Fig. 3). This suggests increasing instability and lower resilience of the current clearwater state, meaning that the probability of a shift to turbid conditions has increased. We posit that the combination of contemporary and palaeolimnological data yields a fuller understanding of changing ecological patterns and processes in shallow lake ecosystems. In the present case, palaeolimnological data provide insight into components of the ecosystem that were not measured in contemporary surveys and that were generally stable, despite shifting water clarity and macrophyte cover.

Acknowledgments This work was supported by the Swedish Research Council (Vetenskapsrådet), the Swedish Environmental Protection Agency (WATERS project) and The Royal Physiographical Society in Lund (Kungliga Fysiografiska Sällskapet i Lund). We thank Karl Holmström at Ekologgruppen and Torbjörn Röhr at Fortifikationsverket for providing us with water-level and chemistry data, Alice Nicolle, Johannes Edvardsson and Petra Bragée for fieldwork and laboratory assistance and Ingemar Renberg for lending us the crust-freeze sampler and assisting with sediment subsampling in Umeå. Two anonymous reviewers are thanked for their valuable comments and suggestions.

Open Access This article is distributed under the terms of the Creative Commons Attribution License which permits any use, distribution, and reproduction in any medium, provided the original author(s) and the source are credited.

\section{References}

Almestrand A, Lundh A (1951) Studies on the vegetation and hydrochemistry of Scanian lakes. 1. Higher aquatic vegetation. Gleerup, Lund

Andersen T, Carstensen J, Hernandez-Garcia E, Duarte CM (2009) Ecological thresholds and regime shifts: approaches to identification. Trends Ecol Evol 24:49-57

Appleby PG (2001) Chonostratigraphical techniques in recent sediments. In: Last W, Smol JP (eds) Tracking environmental change using lake sediments. Volume 1: basin analysis, Coring and chronological techniques. Kluwer, Dordrecht, pp 171-203

Battarbee R, Kneen MJ (1982) The use of electronically counted microspheres in absolute diatom analysis. Limnol Oceanogr 27:184-188

Battarbee R, Jones V, Flower RJ, Cameron NG, Bennion H, Carvalho L, Juggins S (2001) Diatoms. In: Smol J, Birks H, Last W (eds) Tracking environmental change using lake sediments. Volume 3: terrestrial, Algal and siliceous indicators. Kluwer, Dordrecht, pp 155-202

Battarbee R, Anderson N, Jeppesen E, Leavitt P (2005) Combining palaeolimnological and limnological approaches in assessing lake ecosystem response to nutrient reduction. Freshw Biol 50:1772-1780

Bennion H, Appleby P (2001) An assessment of recent environmental change in Llangorse Lake using palaeolimnology. Aquatic Conserv Mar Freshw Ecosyst 9:361-375 
Bennion H, Juggins S, Anderson NJ (1996) Predicting epilimnetic phosphorus concentrations using an improved diatom-based transfer function and its application to Lake Eutrophication management. Environ Sci Technol 30: 2004-2007

Bennion H, Monteith D, Appleby P (2000) Temporal and geographical variation in the English Lake District: evidence from (sub)fossil diatoms and aquatic macrophytes. Freshw Biol 45:394-412

Blindow I (1992a) Decline of charophytes during eutrophication: a comparison to angiosperms. Freshw Biol 28:9-14

Blindow I (1992b) Long- and short-term dynamics of submerged macrophytes in two shallow eutrophic lakes. Freshw Biol 28:15-27

Blindow I, Hargeby A, Andersson G (2002) Seasonal changes of mechanisms maintaining clear water in a shallow lake with abundant Chara vegetation. Aquat Bot 72:315-334

Blindow I, Hargeby A, Meyercordt J, Schubert H (2006) Primary production in two shallow lakes with contrasting plant form dominance: a paradox of enrichment? Limnol Oceanogr 51:2711-2721

Brönmark C, Hansson LA (2005) The biology of lakes and ponds. Oxford University Press, Oxford

Carstensen J, Conley DJ, Andersen JH, Aertebjerg G (2006) Coastal eutrophication and trend reversal: a Danish case study. Limnol Oceanogr 51:398-408

Choudhary P, Routh J, Chakrapani GJ (2010) Organic geochemical record of increased productivity in Lake Naukuchiyatal, Kumaun Himalayas, India. Environ Earth Sci 60:837-843

Collie J, Richardson K, Steele J (2004) Regime shifts: can ecological theory illuminate the mechanisms? Prog Ocean 60:281-302

Conley DJ, Schelske C (2001) Biogenic Silica. In: Smol J, Birks $\mathrm{H}$, Last W (eds) Tracking environmental change using lake sediments. Vol. 3: terrestrial, algal and siliceous indicators. Kluwer, Dordrecht, pp 281-293

Conley DJ, Carstensen J, Vaquer-Sunyer R, Duarte CM (2009) Ecosystem thresholds with hypoxia. Hydrobiologia 629: 21-29

Dearing JA (2008) Landscape change and resilience theory: a palaeoenvironmental assessment from Yunnan, SW China. Holocene 18:117-127

De'ath G (2012) mvpart: multivariate partitioning. R package version 16-0

De'ath G, Fabricius K (2000) Classification and regression trees: a powerful yet simple technique for ecological data analysis. Ecology 81:3178-3192

Duarte CM, Conley DJ, Carstensen J, Sanchez-Camacho M (2009) Return to Neverland: shifting Baselines Affect Eutrophication Restoration Targets. Estuaries Coasts 32: 29-36

Ficken KJ, Li B, Swain DL, Eglinton G (2000) An n-alkane proxy for the sedimentary input of submerged/floating freshwater aquatic macrophytes. Org Geochem 31:745-749

Forsberg C (1964) The vegetation changes in Lake Tåkern. Svensk Botanisk Tidskrift 58:44-54

Håkansson H (2002) A compilation and evaluation of species in the general (sic!) Stephanodiscus, Cyclostephanos and Cyclotella with a new genus in the family Stephanodiscaceae. Diatom Res 17:1-139
Hansson L-A, Nicolle A, Brönmark C, Hargeby A, Lindström $\AA$, Anderson G (2010) Waterfowl, macrophytes, and the clear water state of shallow lakes. Hydrobiologia 646: 101-109

Hargeby A, Blindow I, Andersson G (2007) Long-term patterns of shifts between clear and turbid states in Lake Krankesjön and Lake Tåkern. Ecosystems 10:28-35

Hill MO (1973) Diversity and evenness: a unifying notation and its consequences. Ecology 54:427-432

Hobbs WO, Hobbs JMR, LaFrançois T, Zimmer KD, Theissen KM, Edlund MB, Michelutti N, Butler MG, Hanson MA, Carlson TJ (2012) A 200-year perspective on alternative stable state theory and lake management from a biomanipulated shallow lake. Ecol Appl 22:1483-1496

Jeppesen E, Sondergaard M, Pedersen AR, Juergens K, Strzelczak A, Lauridsen TL, Johansson LS (2007) Salinity induced regime shift in shallow brackish lagoons. Ecosystems 10:47-57

Karlsson J, Lindgren A, Rudebeck G (1976) Drastiska förändringar i vegetation och fågelfauna i Krankesjön och Björkesåkrasjön 1973-1976 [Drastical changes in vegetation and bird fauna in Lakes Krankesjön and Björkesåkrasjön 1973-1976]. Anser 15:165-184

Krammer K, Lange-Bertalot H (1986) Baccilariophyceae. 1. Naviculaceae. In: Ettl H, Gärtner G, Gerloff J, Heynig H, Mollenhauer D (eds) Süßwasserflora von Mitteleuropa, vol 2. Gustav Fischer Verlag, Stuttgart

Krammer K, Lange-Bertalot H (1988) Bacillariophyceae. 2. Bacillariaceae, Epithemiaceae, Surirellaceae. In: Ettl H, Gärtner G, Gerloff J, Heynig H, Mollenhauer D (eds) Süßwasserflora von Mitteleuropa, vol 2. Gustav Fischer Verlag, Stuttgart

Krammer K, Lange-Bertalot H (1991a) Bacillariophyceae. 3. Centrales, Fragilariaceae, Eunotiaceae. In: Ettl H, Gärtner G, Gerloff J, Heynig H, Mollenhauer D (eds) Süßwasserflora von Mitteleuropa, vol 2. Gustav Fischer Verlag, Stuttgart

Krammer K, Lange-Bertalot H (1991b) Bacillariophyceae. 4. Achnanthaceae, Kritische Ergänzungen zu Navicula (Lineolatae) und Gomphonema. In: Ettl H, Gärtner G, Gerloff J, Heynig H, Mollenhauer D (eds) Süßwasserflora von Mitteleuropa, vol 2. Gustav Fischer Verlag, Stuttgart

Lange-Bertalot H (1999) Neue Kombinationen von Taxa aus Achnanthes Bory (sensu lato). In: Lange-Bertalot H (ed) Iconographia diatomologica. Annotated diatom micrographs, vol. 6. Phytogeography-diversity-taxonomy. Koeltz Scientific Books, Köningstein

Lange-Bertalot H, Metzeltin D (1996) Indicators of oligotrophy-800 taxa representative of three ecologically distinct lake types, carbonate buffered-oligodystrophic-weakly buffered soft water. In: Lange-Bertalot $\mathrm{H}$ (ed) Iconographia diatomologica. Annotated diatom micrographs, vol 2. ecology, diversity, taxonomy. Koeltz Scientific Books, Königstein

Lees K, Pitois S, Scott C, Frid C, Mackinson S (2006) Characterizing regime shifts in the marine environment. Fish Fish $7: 104-127$

McGowan S, Leavitt P, Hall R, Anderson N, Jeppesen E, Odgaard B (2005) Controls of algal abundance and community composition during ecosystem state change. Ecology 86:2200-2211 
Meyers P (2003) Applications of organic geochemistry to paleolimnological reconstructions: a summary of examples from the Laurentian Great Lakes. Org Geochem 34:261-289

Mur LR, Skulberg OM, Utkilen H (1999) Cyanobacteria in the environment. In: Chorus I, Bartram J (eds) Toxic cyanobacteria in water: a guide to their public health consequences, monitoring and management. E \& FN Spon, London

Oksanen J, Kindt R, Legendre P, O'Hara B, Henry M, Stevens H (2012) Vegan: community ecology package. R Package version $2.0-5$

Renberg I (1981) Improved methods for sampling, photographing and varve-counting of varved lake sediments. Boreas 10:255-258

Round FE, Bukhtiyarova L (1996) Four new genera based on Achnanthes (Achnanthidium) together with a re-definition of Achnanthidium. Diatom Res 11:345-361

Sayer CD, Hoare DJ, Simpson GL, Henderson ACG, Liptrot ER, Jackson MJ, Appleby PG, Boyle JF, Jones JI, Waldock MJ (2006) TBT causes regime shifts in shallow lakes. Environ Sci Technol 40:5269-5275

Sayer CD, Davidson TA, Jones JI, Langdon PG (2010) Combining contemporary ecology and palaeolimnology to understand shallow lake ecosystem change. Freshw Biol 55:487-499

Scheffer M, Carpenter SR (2003) Catastrophic regime shifts in ecosystems: linking theory to observation. Trends Ecol Evol 18:648-656

Scheffer M, Jeppesen E (2007) Regime shifts in shallow lakes. Ecosystems 10:1-3

Scheffer M, van Nes EH (2007) Shallow lakes theory revisited: various alternative regimes driven by climate, nutrients, depth and lake size. Hydrobiologia 584:455-466

Scheffer M, Hosper S, Meijer M, Moss B, Jeppesen E (1993) Alternative equilibria in shallow lakes. Trends Ecol Evol $8: 275-279$
Scheffer M, Carpenter S, Foley J, Folke C, Walker B (2001) Catastrophic shifts in ecosystems. Nature 413:591-596

Smol J, Wolfe A, Birks H, Douglas M, Jones V, Korhola A, Pienitz R, Rühland K, Sorvari S, Antoniades D, Brooks SJ, Fallu MA, Hughes M, Keatley BE, Laing TE, Michelutti N, Nazarova L, Nyman M, Paterson AM, Perren B, Quinland R, Rautio M, Saulnier-Talbot E, Siitoneni S, Solovieva N, Weckström J (2005) Climate-driven regime shifts in the biological communities of arctic lakes. Proc Natl Acad Sci USA 102:4397-4402

Spencer M, Birchenough SNR, Mieszkowska N, Robinson LA, Simpson SD, Burrows MT, Capasso E, Cleall-Harding P, Crummy J, Duck C, Eloire D, Frost M, Hall AJ, Hawkins SJ, Johns DG, Sims DW, Smyth TJ, Frid CLJ (2011) Temporal change in UK marine communities: trends or regime shifts? Mar Ecol Evolut Perspect 32:10-24

Struyf E, Conley DJ (2009) Silica: an essential nutrient in wetland biogeochemistry. Front Ecol Env 7:88-94

Swanberg PO (1931) Krankesjön, ett fåglarnas paradis [Krankesjön, a paradise for birds]. Natur och kultur, Stockholm

Thomasson K (1956) Om den biocönotiska dynamiken i grunda sjöar. Några synpunkter på Tåkerns oroväckande utveckling. [On the biocoenotic dynamics of shallow lakes. Some views on the worrying development of Lake Tåkern]. In: Engström K, Esping L-E (eds) Sveriges Natur, Årsbok, vol 46. Svenska Naturskyddsföreningen, Stockholm, pp 145-151

van Nes EH, Rip WJ, Scheffer M (2007) A theory for cyclic shifts between alternative stable states in shallow lakes. Ecosystems 10:17-28

Williams DM, Round FE (1987) Revision of the genus Fragilaria. Diatom Res 2:267-288

Zimmer KD, Hanson MA, Herwig BR, Konsti ML (2009) Thresholds and stability of alternative regimes in shallow prairie-parkland lakes of central North America. Ecosystems 12:843-852 